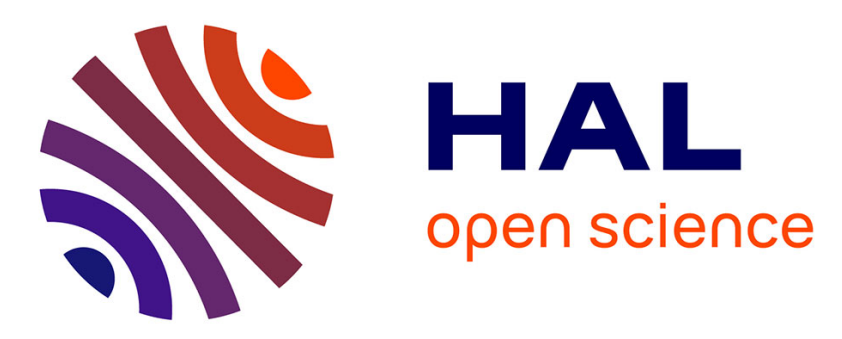

\title{
Sequencing biological acidification of waste-activated sludge aiming to optimize phosphorus dissolution and recovery
}

Felipe Guilayn, Etienne Braak, Simon Piveteau, Marie-Line Daumer

\section{- To cite this version:}

Felipe Guilayn, Etienne Braak, Simon Piveteau, Marie-Line Daumer. Sequencing biological acidification of waste-activated sludge aiming to optimize phosphorus dissolution and recovery. Environmental Technology, 2017, 38 (11), pp.1399-1407. 10.1080/09593330.2016.1230653 . hal-01606667

\section{HAL Id: hal-01606667 https://hal.science/hal-01606667}

Submitted on 26 May 2020

HAL is a multi-disciplinary open access archive for the deposit and dissemination of scientific research documents, whether they are published or not. The documents may come from teaching and research institutions in France or abroad, or from public or private research centers.
L'archive ouverte pluridisciplinaire HAL, est destinée au dépôt et à la diffusion de documents scientifiques de niveau recherche, publiés ou non, émanant des établissements d'enseignement et de recherche français ou étrangers, des laboratoires publics ou privés. 


\section{Sequencing biological acidification of waste activated sludge aiming to optimize phosphorus dissolution and recovery}

\section{Felipe Guilayn, Etienne Braak, Simon Piveteau \& Marie-Line Daumer}

To cite this article: Felipe Guilayn, Etienne Braak, Simon Piveteau \& Marie-Line Daumer (2016): Sequencing biological acidification of waste activated sludge aiming to optimize phosphorus dissolution and recovery, Environmental Technology, DOI: 10.1080/09593330.2016.1230653

To link to this article: http://dx.doi.org/10.1080/09593330.2016.1230653

Accepted author version posted online: 14

Sep 2016.

Published online: 14 Sep 2016

Submit your article to this journal $[\pi$

à

View related articles ๔

View Crossmark data $₫$ 
Publisher: Taylor \& Francis \& Informa UK Limited, trading as Taylor \& Francis Group Journal: Environmental Technology

DOI: $10.1080 / 09593330.2016 .1230653$

SEQUENCING BIOLOGICAL ACIDIFICATION OF WASTE ACTIVATED SLUDGE AIMING TO OPTIMIZE PHOSPHORUS DISSOLUTION AND RECOVERY

Felipe GUILAYN ${ }^{\mathrm{a}, 1}$, Etienne BRAAK ${ }^{\mathrm{a}}$, Simon PIVETEAU ${ }^{\mathrm{a}}$, Marie-Line DAUMER ${ }^{\mathrm{a}, *}$ alrstea,UR OPAALE, 17 avenue de Cucillé, 35044 Rennes Cedex, France.

${ }^{1}$ First author. Present affiliation : INRA, Laboratoire de Biotechnlogie de l'Environnement, 102, Avenue des Etangs, 11100 Narbonne, France. E-mail address : felipe.guilayn@supagro.inra.fr. Tel.: +33 (0)6 48 223383

*Corresponding author. E-mail address: marie-line.daumer@irstea.fr. Tel.: +33 (0)2 23482129

Acknowledgements

The authors wish to thank the financial support from the French National Agency for Water and Aquatic Environments (ONEMA). 


\begin{abstract}
Phosphorus (P) recovery in wastewater treatment plants (WWTP) as pure crystals such as struvite (MgNH4PO4.6H2O), potassium struvite (KMgPO4.6H2O) and calcium phosphates (e.g. Ca3(PO4)2) is an already feasible technique that permits the production of green and marketable fertilizers and the reduction of operational costs. Commercial crystallizers can recovery more than $90 \%$ of soluble P. However, most of the P in WWTP sludge is unavailable for the processes (not dissolved). P solubilization and separation are thus the limiting steps in Pcrystallization. With an innovative two-step sequencing acidification strategy, the current study has aimed to improve biological P solubilization on waste activated sludge (WAS) from a fullscale plant. In the first step (P-release), low charges of organic waste were used as co-substrates of WAS pre-fermentation, seeking to produce volatile fatty acids to feed the P-release by Polyphosphate-accumulating organisms (PAO), while keeping its optimal metabolic $\mathrm{pH}$ (6 to 7). In this phase, milk serum, WWTP grease, urban organic waste and collective restaurant waste were individually applied as co-substrates. In the second step (P-dissolution), $\mathrm{pH} 4$ was aimed as it allows the dissolution of the most common precipitated species of P. Biological acidification was performed by white sugar addition, as a carbohydrate-rich organic waste model, which was compared to chemical acidification by $\mathrm{HCl}$ (12M) addition. With short retention times (48-96 hours) and without inoculum application, all experiences succeeded on $\mathrm{P}$ solubilization (37-55\% of soluble P), principally when carbohydrate-rich co-substrates were

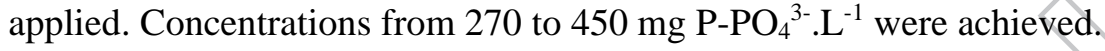

Keywords: phosphorus solubilization, nutrient recovery, waste activated sludge, WAS fermentation, organic waste. 


\section{Introduction}

Phosphorus (P) is the key element of life [1, 2]. According to Gowariker, Krishnamurthy [3], P is an essential part of nucleoproteins that control cells division and nucleic acids molecules. Acelas, Flórez [4] highlight that there is no substitute for P, a fundamental element to all living organisms and an essential nutrient in food production.

During the past centuries, we have changed radically our impact in the P cycle: we have entered in a linear consumption logic in which large amounts of $\mathrm{P}$ are mined from specific phosphate reserves and transported to crops all over the world [5]. Different scientists and producers associations estimate the lifetime of phosphate rock reserves by being from 50 to 270 years [6, 7]. It is a similar scenery to oil reserves ending, but $\mathrm{P}$ cannot be replaced in a situation of scarcity and growing prices [5].

The issue of $\mathrm{P}$ in sanitary engineering started after it was identified as the main responsible for eutrophication in water bodies [5]. Initially, $\mathrm{P}$ was removed by simple chemical precipitation and later with more complex processes as the Enhanced Biological Phosphorus Removal (EBPR) [8]. More often, EBPR is complemented by chemical precipitation to reach the legal limits [9].

However, chemical precipitation, yet the most used technique, increases sludge production, its toxicity and its disposal costs [10]. EBPR also produces large volumes of sludge and most of the biologically concentrated $\mathrm{P}$ is released again under anaerobic conditions [11]. It is the case of anaerobic digestion (AD), known as the most used process for sludge stabilization. Thereby, in wastewater treatment plants (WWTP) with EBPR processes, the dewatering liquors of digested sludge are highly concentrated in nutrients and can contribute to up to $20 \%$ of $\mathrm{P}$ and $\mathrm{N}$ affluent load when returned to the plant's head [12]. The AD of sludge results in ammonium, magnesium, potassium and phosphate release thus crystals such as struvite (magnesium ammonium phosphate hexahydrate, MgNH4PO4.6H2O) can be spontaneously formed inside the digesters, pipes and other equipment [13]. However, the crystallization processes can be controlled to become a source of revenues to the operators of WWTP. Struvite, for instance, is a great fertilizer with several environmental advantages [10].

Currently, most of the $\mathrm{P}$ crystallization processes are located after the anaerobic digestion of sludge. Commercial struvite crystallizers, for example, allow above $90 \%$ of soluble P recovery rates [10]. These processes prevent nutrients return to the head of the treatment plant, but they are not efficient to prevent maintenance issues induced by $\mathrm{P}$ crystallization inside the anaerobic reactor or in equipment downstream. Consequently, process optimization opportunities are mostly focused now on increasing the amount of soluble $\mathrm{P}$ to increase $\mathrm{P}$ recycling rate before anaerobic digestion.

Chemical acidification or waste activated sludge (WAS) pre-fermentation have been tested to solubilize $\mathrm{P}$ either by dissolving the mineral forms or by releasing the $\mathrm{P}$ from the Polyphosphate-Accumulating Organisms (PAO) $[6,14,15,16,17]$. In that case, a separation step is performed between the P-dissolution stage and the digester. The liquid phase enters the P-recycling process and the sludge is sent to the anaerobic digester. Pre-fermentation results in $\mathrm{pH}$ reduction, $\mathrm{P}$ and ammonium release [18]. Since low $\mathrm{pH}$ avoids precipitation and so allows keeping the released $\mathrm{P}$ in solution, the lower the $\mathrm{pH}$, the greater the amount of $\mathrm{P}$ dissolved. Our previous works showed that depending on the charge and the biochemical composition of the co-substrates used for the pre-fermentation, it was possible to biologically decrease the $\mathrm{pH}$ down to 3 under controlled conditions. However, in sludge from WWTP combining EBPR and chemical process for $\mathrm{P}$ removal, $\mathrm{P}$ is mainly intracellular in $\mathrm{PAO}$ and we observed that $\mathrm{P}$ dissolution was low because $\mathrm{P}$ release by the $\mathrm{PAO}$ was inhibited when $\mathrm{pH}$ was lower than 5 [19]. Excessively low $\mathrm{pH}$ increases the $\mathrm{pH}$ gradient between the internal and external parts of cell membranes and thus decreases the efficiency in substrate transporting inside the cell, resulting in a smaller quantity of released $\mathrm{P}$ by absorbed substrate, as described by Deronzier and Choubert [20]. On the other hand, P released by the PAO was precipitated as calcium or iron phosphates when the $\mathrm{pH}$ was above 5. So, the parameters to optimize P-release from PAO, among which neutral $\mathrm{pH}$, tend to readily precipitate the $\mathrm{P}$ with available cations as iron, aluminum or calcium depending on the process used for phosphorus removal in the WWTP. 
We have recently presented a fermentation batch test that can be easily applied to assess and predict biologically releasable P [19]. However, we have noticed that biological P solubilization could be theoretically optimized by separating intracellular P-release and P dissolution in a twostep process. The P-release step needs an anaerobic condition, volatile fatty acids availability and has an optimal $\mathrm{pH}$ in the neutral range, while the $\mathrm{P}$ dissolution step relies in the $\mathrm{pH}$ reduction, which can be achieved by chemical dosing or by biological fermentation. This paper presents the first experiments of this concept of sequencing acidification. In the proposed process, a weak WAS pre-fermentation is performed with low charges of organic co-substrates and is sequentially complemented with a pH drop induced either by the dosage of a strong acid or biologically with white sugar application to stimulate acidogenesis, simulating carbohydraterich organic waste.

Materials and methods

WAS samples

The WAS sludge used for the tests was obtained from a WWTP treating 360000 population equivalent. It was sampled after thickening by a belt press. Secondary treatment in the WWTP consists of oxidation ditches designed to achieve Enhanced Biological Phosphorus Removal (EBPR). $\mathrm{FeCl}_{3}$ is applied as complementary $\mathrm{P}$ treatment to ensure the legislation limits. Table 1 shows WAS characteristics for each test at the moment of experience launching (after storage at $\left.4^{\circ} \mathrm{C}\right)$.

Raw samples analysis (thickened WAS) showed that the WWTP was operating on stationary state, once the main parameters were always found to be stable $(\mathrm{pH}$, total solids, volatile solids, total phosphorus, etc.) compared to several sampling that we had done before.

\section{Analysis}

Total solids (TS), volatile solids (VS), total Kjeldahl nitrogen (TKN) and chemical oxygen demand (COD), were measured with standard methods [21]. After an acidic mineralization $\left(110^{\circ} \mathrm{C}, 1 \mathrm{bar}, 60 \mathrm{~min}\right)$, total phosphorus (TP) was analyzed by the ascorbic acid method using an automate spectrophotometry (Gallery, Thermo Scientific, method 984366).

The ionic composition of the supernatants was measured after centrifugation $\left(4^{\circ} \mathrm{C}, 20000 \mathrm{~g}\right)$ and filtration on $0.45 \mu \mathrm{m}$ polypropylene membrane with both anion $\left(\mathrm{Cl}^{-}, \mathrm{NO}_{2}^{-}, \mathrm{NO}_{3}{ }^{-}, \mathrm{PO}_{4}{ }^{3-}, \mathrm{SO}_{4}{ }^{2-}\right)$ and cation $\left(\mathrm{Na}^{+}, \mathrm{NH}_{4}^{+}, \mathrm{Mg}^{2+}, \mathrm{Ca}^{2+}, \mathrm{K}^{+}\right)$chromatography. A Metrohm 940 Professional Vario IC was equipped with a Metrosep A sup 5 anionic column and a Metrosep C4 -250/4,0 column for cations.

Total dissolved iron $\left(\mathrm{Fe}^{2+}\right.$ and $\mathrm{Fe}^{3+}$ ) was measured by an automate spectrophotometry (Gallery, Thermo Scientific, method 984326).

Co-substrates

The co-substrates were selected to match the local reality of Brittany (France): milk serum, WWTP grease, urban organic waste and collective restaurant waste were individually used as co-substrates. Urban organic waste, collective restaurant waste, milk serum and WWTP grease were stored at $-20^{\circ} \mathrm{C}$. All solid co-substrates were cryogenized and triturated to form a homogeneous mixture. The co-substrates were characterized in total COD (TCOD), TP, carbohydrate, lipid and protein contents. The results of co-substrates characterization are shown in Table 2.

\section{Chemical acidification}

Chemical acidification tests were run to estimate the fraction of P released by chemical mechanism during biological acidification. Hydrochloric acid (12 M) was used as acid. Dilutions caused by the acid dosage were neglected. $\mathrm{pH}$ was maintained stable for $15 \mathrm{~min}$ at each $\mathrm{pH}$ value under continuous stirring (250 RPM) and then lowered from 1 unit till reaching $\mathrm{pH}$ 2. Acidified waste activated sludge was sampled at every $\mathrm{pH}$ unit. Soluble $\mathrm{P}\left(\mathrm{P}_{-} \mathrm{PO}_{4}{ }^{3-}\right)$ and total dissolved iron $\left(\mathrm{Fe}^{2+}+\mathrm{Fe}^{3+}\right)$ concentrations were determined in the supernatant. $\mathrm{P}-\mathrm{PO}_{4}{ }^{3-}$ dissolution was found to be described by a polynomial function, which was used to estimate the contribution of chemical dissolution during the biological process as described by Braak, Auby [19]. The iron dissolution curve was described by a polynomial function. 


\section{Biological acidification tests}

The reactors used on sludge fermentation tests were Erlenmeyer flasks with a total volume of $1280 \mathrm{ml}$, filled with $640 \mathrm{ml}$ during tests. The reactors were placed on heating plates with magnetic stirring. The reaction temperature was set to $35^{\circ} \mathrm{C}$, which corresponds to a mesophilic condition, such as most of the anaerobic digesters in France [22]. A thermally insulated box was used as a cover to promote a homogeneous temperature.

The reactors were closed with a rubber septum, which allowed the insertion of needles for pressure measurement, gas collection or injection, as well as reagents dosage. In every experience start or flask opening, the atmosphere was inerted with nitrogen gas for at least 20 minutes $\left(1 \mathrm{~mm} \cdot \mathrm{min}^{-1}\right)$. Glass taps were adapted in the reactor's bottom in order to allow sampling without opening the reactors. The internal pressure generated by the gas production during fermentation ensured that no oxygen was reintroduced during sampling. Overpressure was daily removed with a needle through the rubber septum to avoid vial burst. Repeatability was assessed prior to the operation of these experiments by triplicates with sugar at loads of 2-5 gCOD.gVS ${ }^{-1}$ and provided more than $95 \%$ repeatability on $\mathrm{pH}$ and soluble P. Consequently, the tests were not normally duplicated.

\section{Sequencing acidification}

The principle of the sequencing acidification is presented in Figure 1. The first step, in which Prelease takes place, was performed in reactors as described above. In this phase, volatile fatty acids (VFAs) must be produced to enhance intracellular P-release by PAO. However, the cosubstrate charge must be limited to avoid an excessive $\mathrm{pH}$ reduction and the consequent decrease in the efficiency of PAO's metabolism. Previous works showed that the ratio of 0.2 gCOD.gVS ${ }^{-1}$ brings enough carbon for P release, keeping the $\mathrm{pH}$ above 6 [23]. A control test without co-substrate was performed in the same conditions. After $48 \mathrm{~h}$, a second $\mathrm{P}$ dissolution step was performed, where $\mathrm{pH}$ was reduced to dissolve the released $\mathrm{P}$ which could be precipitated with cations and other previous non-soluble forms. Acidification was performed biologically by the addition of sucrose (white sugar) as a carbohydrate-rich co-substrate model $\left(0.5\right.$ gCOD.gVS ${ }^{-1}$ during $48 \mathrm{~h}$ ) and by chemical dosage ( $\left.\mathrm{HCl} 12 \mathrm{M}\right)$. Two strategies of chemical acidification were evaluated only in the control test: sample acidification to $\mathrm{pH} 4$ (R2) and reactor acidification to $\mathrm{pH} 4$ with reaction continuation (R1).

Excluding iron phosphates, $\mathrm{pH} 4$ is sufficient to prevent readily precipitation of released $\mathrm{P}$ with amorphous calcium phosphate and struvite, the most common forms according to previous experiences. Stronger acidifications could induce operational problems such as excessive chemical needs on $\mathrm{pH}$ increasing to allow struvite crystallization, methanogenesis inhibition and inefficiency on dewatering processes.

The experiment planning is summarized in Table 3. 


\section{Results and discussion}

Chemical acidification

Results of the chemical acidification test are presented in Figure 2, in terms of soluble P and total soluble iron as function of $\mathrm{pH}$.

Soluble P presented a second order polynomial tendency with a maximum value of $11,2 \%$ of soluble $\mathrm{P}$ at $\mathrm{pH}$ 3.4. This result was consistent if compared with previous publications [19] in which around $15 \%$ of soluble $\mathrm{P}$ was found at $\mathrm{pH} 2$ with non-stored WAS from the same WWTP.Total soluble iron also presented a second order polynomial tendency with a maximum measured value of $105 \mathrm{mg} . \mathrm{L}^{-1}$ at $\mathrm{pH} 2$.

$\mathrm{pH}$ and $\mathrm{P}$ evolution

After $48 \mathrm{~h}$ of P-release step, it was observed a slightly lower $\mathrm{pH}$ with lactoserum as co-substrate (5.6) and similar values in the other tests: 6.1 to control and WWTP grease and 5.9 to the restaurant and urban organic wastes (Figure 3).

A greater difference is observed on soluble $\mathrm{P}$, which represents $19 \%$ of the total $\mathrm{P}$ for the control test and about 30\% with organic co-substrates application (Figure 4). The higher total $\mathrm{P}$ value due to the higher $\mathrm{P}$ supply caused by lactoserum application (Table 2) may partially explain the greater soluble $\mathrm{P}$ amount in this test, but not the difference between the other tests and the control.

Equation 1 (presented on Figure 2) was used to estimate the P amount dissolved exclusively by the $\mathrm{pH}$ decrease. Apparent biologically released $\mathrm{P}$ was calculated (equation 2) by subtracting the amount of soluble $\mathrm{P}$ due to $\mathrm{pH}$ variation from the measured soluble $\mathrm{P}$ value. As the reprecipitated $\mathrm{P}$ is the difference between actual and apparently released $\mathrm{P}$, the $\mathrm{P}$ fraction actually released by the PAO (equation 3) was estimated by subtracting the amount of $\mathrm{P}$ according to equation 1 from the soluble $\mathrm{P}$ value obtained with the chemical acidification to $\mathrm{pH} 4$ just after the P-release step. Actual released $\mathrm{P}$ ranges from $36 \%$ of total $\mathrm{P}$ for control and restaurant waste to $44 \%$ with lactoserum. It is $38 \%$ and $41 \%$ for urban organic waste and WWTP grease respectively (Figure 5). The readily biodegradable COD provided by the lactoserum (a carbohydrate-rich co-substrate) would thus increase by $22 \%$ the P-release by PAO. This effect and the amount of soluble $\mathrm{P}$ provided by this effluent may explain the observed difference. However for restaurant and organic urban wastes, biological P-release is very close to the amount released during the control test. In this case, the higher amount of soluble $\mathrm{P}$ in the tests with co-substrates could be explained by the lower precipitation of released P, which is related to the higher presence of colloidal and particulate organic matter due to the addition of organic waste. Several authors have shown that the presence of organic matter limited P precipitation in effluents [24]. For WWTP grease, these two phenomena may explain the observed difference.

$$
\begin{aligned}
& {\left[\mathrm{P}^{-\mathrm{PO}_{4}}\right]_{\mathrm{cmq}, \mathrm{d}}=-3,9965 \times \mathrm{pH}^{2}+24,942 \mathrm{pH}+46,631\left(\mathrm{R}^{2}=0.9997\right)} \\
& {\left[\mathrm{P}-\mathrm{PO}_{4}\right]_{\text {ap,bio,rel }}=\left[\mathrm{P}-\mathrm{PO}_{4}\right]-\left[\mathrm{P}-\mathrm{PO}_{4}\right]_{\mathrm{cmq}, \mathrm{d}}} \\
& {\left[\mathrm{P}-\mathrm{PO}_{4}\right]_{\text {bio,rel }}=\left[\mathrm{P}-\mathrm{PO}_{4}\right]_{\mathrm{pH} 4}-\left[\mathrm{P}-\mathrm{PO}_{4}\right]_{\mathrm{cmq}, \mathrm{d}}}
\end{aligned}
$$

Where $\left[\mathrm{P}-\mathrm{PO}_{4}\right]_{\mathrm{cmq}, \mathrm{d}}$ is the theoretical soluble $\mathrm{P}$ concentration due only to $\mathrm{pH}$ variation, $\left[\mathrm{P}-\mathrm{PO}_{4}\right]_{\mathrm{ap}, \text { bio,rel }}$ is the apparent biological released $\mathrm{P}$ and $\left[\mathrm{P}-\mathrm{PO}_{4}\right]_{\text {bio,rel }}$ is the actually theoretical released $\mathrm{P}$, which estimates $\mathrm{P}$ precipitation.

After white sugar addition, a quick pH drop was observed from about 6.0 to 4.7 in all tests, but the goal of biological acidification was also $\mathrm{pH} 4$. After that, it remained approximately stable until 96h of reaction (Figure 3). Following the acidification, soluble $\mathrm{P}$ concentrations ( $\left.\mathrm{P}^{-} \mathrm{PO}_{4}{ }^{3-}\right)$ increased and reached about $40 \%$ of the total P after $96 \mathrm{~h}$ in all tests. A maximum of $52 \%$ soluble $\mathrm{P}$ was obtained in the control test with a retention time of $72 \mathrm{~h}$ (Figure 4). After P-release step, 24h of biological acidification (total retention time of 72h) contributed with more 6-10\% (actual waste) and 33\% (both control tests) of soluble P, but there was no 
significant extra P solubilization with $48 \mathrm{~h}$ of biological acidification (total of $96 \mathrm{~h}$ ). Soluble P results of biological acidification (sugar addition) were systematically lower than the results of chemical adjustment as sequencing acidification strategy (Figure 5). Biological acidification reached $\mathrm{pH} 4.7$ and chemical acidification was performed to achieve $\mathrm{pH} 4$. This $\mathrm{pH}$ difference may explain different soluble $\mathrm{P}$ concentrations since it opposes precipitation of $\mathrm{P}$ with available cations. Tests with higher charges of sugar $\left(>0.5\right.$ gCOD.VS $\left.{ }^{-1}\right)$ could be performed in order to achieve $\mathrm{pH} 4$ on biological acidification and to compare results.

Regardless of the applied method, soluble P did not exceed 55\%, what is significantly lower than the $75 \%$ value previously obtained by directly adding white sugar on 0.5 gCOD.gVS ${ }^{-1}$ organic charge at the beginning of the pre-fermentation with WAS from the same WWTP [19]. In the present tests, the smaller charges intentionally applied to limit $\mathrm{pH}$ decrease during $\mathrm{P}$ release step has perhaps not provided the needed amount of VFA to properly enhance P-release by PAO. Unfortunately, the limited number of reactors has not allowed a test in those same conditions (white sugar addition on 0.5 gCOD.gVS ${ }^{-1}$ from the beginning), or with higher medium range initial charges (from 0.2 to 0.5 gCOD.gVS ${ }^{-1}$ ), with the exactly same WAS samples. Different P-release times could be tested as well. Furthermore, distinct behaviors depending on sludge sample characteristics and storage must not be ignored.

\section{Cations evolution}

The co-substrates did not provide significant amounts of cations except lactoserum whose concentrations of soluble Ca and $\mathrm{K}$ ions are respectively 1301 and $1500 \mathrm{mg} . \mathrm{L}^{-1}$ and WWTP grease whose concentration on soluble Ca ion is $368 \mathrm{mg} . \mathrm{L}^{-1}$.

Except to iron, it was found an increase in all cations concentrations during the pre-fermentation phase in which P-release is performed. $\mathrm{Mg}$ and $\mathrm{K}$ dissolution is related to the co-transportation of these cations during intracellular P-release by PAO as described by Barat, Montoya [25] (Figure 6).

Ammonium concentration increase was probably caused by nitrogen mineralization during cosubstrates proteins degradation (Figure 6D). This could explain the higher $\mathrm{pH}$ compared to previous works with white sugar alone.

Ammonium and potassium salts are very soluble reaching high concentrations already after prefermentation; therefore, chemical acidification to $\mathrm{pH} 4$ did not imply a significant increase in these values which were also stable during biological acidification induced by sugar addition.

Calcium ion concentration presented a slight increase during P-release step (pre-fermentation) what is coherent with demonstrations that Ca is not co-transported with P in PAO's metabolism [25]. In contrast, unlike the other cations, chemical acidification after pre-fermentation multiplied its concentration by about 2.5 (Figure 6). These results are consistent with the results of chemical-only acidification.

Dissolved iron concentrations $\left(\mathrm{Fe}^{2+}\right.$ and $\left.\mathrm{Fe}^{3+}\right)$ after chemical acidification of pre-fermented WAS were between 400 and $500 \mathrm{mg} . \mathrm{L}^{-1}$ (Figure 7). These values are greater than those obtained with biological sequencing acidification which does not exceed $280 \mathrm{mg} . \mathrm{L}^{-1}$ at $\mathrm{pH} 4.7$. Soluble iron concentrations were much greater with the application of sequencing acidification than with chemical acidification of WAS without pre-fermentation: 102, 66 and 35 mg. $\mathrm{L}^{-1}$ at $\mathrm{pH}$ 2,3 and 5 respectively. This result confirms the assumptions made in previous works on the role of pre-fermentation metabolism that would turn iron into more sensible to acidification forms [19].

The biological role and the chemical complexity of iron on sewage treatment regarding Precycling still poorly understood, but those are issues beginning to attract scientific interest [9]. 


\section{Struvite crystallization potential}

This session will be dedicated to analyze struvite crystallization potential, since it stills the major industrial interest regarding full scale P-recovery through crystallization processes Desmidt, Ghyselbrecht [26]. Struvite (MgNH4PO4.6H2O) crystallization processes depend mainly on two operational factors: $\mathrm{pH}$ (alkaline) and Mg:N:P molar ratio (greater than 1:1:1) [27]. Magnesium ion is normally the limiting reagent and needs to be dosed [28].

P-rich side streams or process water with phosphorus concentrations greater than $50 \mathrm{mg} . \mathrm{L}^{-1}$ can be considered economically feasible to struvite crystallization [29]. Concentrations from 147 to $257 \mathrm{mg} \mathrm{P}-\mathrm{PO}_{4}{ }^{3-} \cdot \mathrm{L}^{-1}$ were achieved just after P-release step, from 362 to $448 \mathrm{mg} \mathrm{P}-\mathrm{PO}_{4}{ }^{3-} . \mathrm{L}^{-1}$ after chemical sequencing acidification and from 300 to $432 \mathrm{mg} \mathrm{P}-\mathrm{PO}_{4}{ }^{3-} \cdot \mathrm{L}^{-1}$ after biological sequencing acidification.

Medium values of Mg:P, N:P, Mg:Ca and Ca:P molar ratios results from every test are summarized in Table 4. As expected, $\mathrm{Mg}: \mathrm{P}$ is not sufficient, presenting results from 0.3 to 0.4. Mg:Ca ratios are low (0.4-0.6) and Ca:P ratios are close to 1 . Mg should thus be dosed to reach Mg:Ca $>2$, since Ca-P precipitations are prior to struvite and may partially [30] or even totally [4] inhibit struvite formation. Impurities as dicalcium phosphate dehydrate, octacalcium phosphate and hydroxyapatite are the most common calcium phosphates in aqueous solutions and should be expected [31].

$\mathrm{N}$ :P values are high ( $>2)$, so it should not be a limiting factor on struvite crystallization, although N-recycling potential would be limited by soluble P availability. 
Conclusions and perspectives

Our previous works have shown that a strong acidification, induced by a large amount of easily biodegradable organic matter from the beginning of the pre-fermentation of WAS may reduce biological P-release by PAO. Therefore, we sought to dissociate P-release and P-dissolution by applying a two-step sequencing acidification strategy. This paper presented its first results and the main conclusions are shown below:

- Sequencing acidification with chemical dosage was more effective (about $50 \%$ of soluble $\mathrm{P}$ at $\mathrm{pH} 4$ ) than biological sequencing acidification (about $40 \%$ at $\mathrm{pH} 4.7$ ) but both presented better results than chemical-only acidification (maximum of $11 \%$ at $\mathrm{pH}$ 3.4).

- Biological acidification with the applied organic charge did not reach $\mathrm{pH} 4$, which has been observed in previous work. The great amount of ammonium mineralized during the first 48 hours of P-release step may have increased the buffering capacity and may explain this effect.

- Sequencing acidification strategy showed to be less effective than the input of a larger amount of easily biodegradable COD at the beginning of the tests, as performed in previous works.

- The role of biological metabolism on iron dissolution was confirmed. 


\section{References}

1. Karl DM. Aquatic ecology: Phosphorus, the staff of life. Nature. 2000;406:31-3.

2. White A, Dyhrman S. The marine phosphorus cycle. Front Microbiol. 2013;4.

3. Gowariker VR, Krishnamurthy VN, Gowariker S, Dhanorkar M. The fertilizer encyclopedia : overviewing plant growth, soil fertility, fertilizer chemistry \& nutrient management. Pune, India: Vasudha Research \& Publications; 2005.

4. Acelas NY, Flórez E, López D. Phosphorus recovery through struvite precipitation from wastewater: effect of the competitive ions. Desalin Water Treat. 2015;54:2468-79.

5. Ashley K, Cordell D, Mavinic D. A brief history of phosphorus: from the philosopher's stone to nutrient recovery and reuse. Chemosphere. 2011;84:737-46. Epub 2011/04/13.

6. Antakyali D, Meyer C, Preyl V, Maier W, Steinmetz H. Large-scale application of nutrient recovery from digested sludge as struvite. Water Pract Tech. 2013;8.

7. Cordell D, Drangert J-O, White S. The story of phosphorus: Global food security and food for thought. Global Environ Chang. 2009;19:292-305.

8. Barnard JL. Biological nutrient removal without the addition of chemicals. Water Res. 1975;9:485-90.

9. Wilfert P, Kumar PS, Korving L, Witkamp G-J, van Loosdrecht MCM. The Relevance of Phosphorus and Iron Chemistry to the Recovery of Phosphorus from Wastewater: A Review. Environ Sci Technol. 2015;49:9400-14.

10. Shu L, Schneider P, Jegatheesan V, Johnson J An economic evaluation of phosphorus recovery as struvite from digester supernatant. Bioresource Technol. 2006;97:2211-6.

11. Comeau Y, Rabionwitz B, Hall KJ, Oldham WK. Phosphate Release and Uptake in Enhanced Biological Phosphorus Removal from Wastewater. J Water Pollut Control Fed. 1987;59:707-15.

12. Evans TD. Recovering ammonium and struvite fertilisers from digested sludge dewatering liquors. Paper presented at: 4th IWA Specialist Conference on Efficient Use and Management of Urban Water Supply; 2007 May 20-23; Jeju Island.

13. Bhuiyan MI, Mavinic DS, Koch FA. Phosphorus recovery from wastewater through struvite formation in fluidized bed reactors: a sustainable approach. Water science and technology : a journal of the International Association on Water Pollution Research. 2008;57:175-81. Epub 2008/02/01.

14. $\mathrm{Xu} \mathrm{Y,} \mathrm{Hu} \mathrm{H,} \mathrm{Liu} \mathrm{J,} \mathrm{Luo} \mathrm{J,} \mathrm{Qian} \mathrm{G,} \mathrm{Wang} \mathrm{A.} \mathrm{pH} \mathrm{dependent} \mathrm{phosphorus} \mathrm{release}$ from waste activated sludge: contributions of phosphorus speciation. Chem Eng J. 2015;267:260-5.

15. Schauer P, Baur R, Barnard J, Britton A. Controlling Magnesium and Phosphorus to Reduce Struvite Precipitation in Plant Processes and Increase Revenue. Proceedings of the Water Environment Federation, Nutrient Removal. 2009;2009:926-47.

16. Schauer P, Baur R, Barnard J, Britton A. Innovative Phosphorus Control to Turn Struvite Headaches into Increased Revenue. Proceedings of the Water Environment Federation, WEFTEC. 2009;2009:3132-50.

17. Schauer P, Baur R, Barnard J, Britton A. Increasing Revenue While Reducing Nuisance Struvite Precipitation: Pilot Scale Testing of the WASSTRIP Process.

Proceedings of the Water Environment Federation, Nutrient Recovery and Management. 2011;2011:848-65.

18. Chen Y, Jiang S, Yuan H, Zhou Q, Gu G. Hydrolysis and acidification of waste activated sludge at different pHs. Water Res. 2007;41:683-9.

19. Braak E, Auby S, Piveteau S, Guilayn F, Daumer M-L. Phosphorus recycling potential assessment by a biological test applied to wastewater sludge. Environ Technol. 2016;37:1398-407. 
20. Deronzier G, Choubert J-M. Traitement du phosphore dans les petites stations d'épuration à boues activées [Phosphorus treatment in small activated sludge wastewater treatment plants]. Antony: Cemagref Editions, 50p. 2004.

21. Federation WE, American Public Health A. Standard methods for the examination of water and wastewater. American Public Health Association (APHA): Washington, DC, USA. 2005.

22. Reverdy AL, Dieudé-Fauvel E, Ferstler V, Baudez JC. La méthanisation des boues d'épuration urbaines-État des lieux en France et état de l'art [Anaerobic digestion of sewage sludge: French inventory and state of the art]. Techniques Sciences Méthodes. 2012:73-9 \%@ 0299-7258.

23. Braak E, Auby S, Daumer M. Innnovative technique to improve $P$ recycling yield from WWTP sludge by producing high quality fertiliser (struvite). Paper presented at: 16th RAMIRAN Internation Conference Rural-Urban Symbiosis; 2015 Sept. 8-10; Hamburg.

24. Capdevielle A, Sýkorová E, Béline F, Daumer M-L. Effects of organic matter on crystallization of struvite in biologically treated swine wastewater. Environ Technol. 2016;37:880-92.

25. Barat R, Montoya T, Seco A, Ferrer J. The Role of Potassium, Magnesium and Calcium in the Enhanced Biological Phosphorus Removal Treatment Plants. Environ Technol. 2005;26:983-92.

26. Desmidt E, Ghyselbrecht K, Zhang Y, Pinoy L, Van der Bruggen B, Verstraete W, Rabaey K, Meesschaert B. Global Phosphorus Scarcity and Full-Scale P-Recovery Techniques: A Review. Crit Rev Env Sci Tec. 2015;45:336-84.

27. Münch EV, Barr K. Controlled struvite crystallisation for removing phosphorus from anaerobic digester sidestreams. Water Res. 2001;35:151-9.

28. Wu Q, Bishop PL. Enhancing struvite crystallization from anaerobic supernatant. J Environ Eng Sci. 2004;3:21-9.

29. Cornel P, Schaum C. Phosphorus recovery from wastewater: needs, technologies and costs. Water science and technology : a journal of the International Association on Water Pollution Research 2009;59:1069-76.

30. Capdevielle A, Sýkorová E, Biscans B, Béline F, Daumer M-L. Optimization of struvite precipitation in synthetic biologically treated swine wastewater-Determination of the optimal process parameters. J Hazard Mater. 2013;244-245:357-69.

31. Martí N, Pastor L, Bouzas A, Ferrer J, Seco A. Phosphorus recovery by struvite crystallization in WWTPS. Influence of the sludge treatment line operation. Water Res. 2010;44:2371-9. 
Tables

Table 1 - Characteristics of the WAS samples

\begin{tabular}{|l|l|}
\hline Stocking time $\left(4^{\circ} \mathrm{C}\right)$ & $\sim 0$ \\
\hline TS $\left(\mathrm{g} \cdot \mathrm{kg}^{-1}\right)$ & 27 \\
\hline TVS $\left(\mathrm{g} \cdot \mathrm{kg}^{-1}\right)$ & 19 \\
\hline $\mathrm{TSS}\left(\mathrm{g} \cdot \mathrm{kg}^{-1}\right)$ & 25 \\
\hline VSS $\left(\mathrm{g} \cdot \mathrm{kg}^{-1}\right)$ & 18 \\
\hline $\mathrm{TFS}\left(\mathrm{g} \cdot \mathrm{kg}^{-1}\right)$ & 8,1 \\
\hline $\mathrm{pH}$ & 6,8 \\
\hline $\mathrm{TP}\left(\mathrm{g} \cdot \mathrm{kg}^{-1}\right)$ & 0,8 \\
\hline $\mathrm{N}-\mathrm{NH} 4+\left(\mathrm{mg} \cdot \mathrm{L}^{-1}\right)$ & $\mathrm{ND}$ \\
\hline $\mathrm{Ca}{ }^{2+}\left(\mathrm{mg} \cdot \mathrm{L}^{-1}\right)$ & 32 \\
\hline $\mathrm{Mg}^{2+}\left(\mathrm{mg} \cdot \mathrm{L}^{-1}\right)$ & 11 \\
\hline $\mathrm{K}^{+}\left(\mathrm{mg} \cdot \mathrm{L}^{-1}\right)$ & 35 \\
\hline $\mathrm{N}-\mathrm{NO}_{2}^{-}\left(\mathrm{mg} \cdot \mathrm{L}^{-1}\right)$ & 0,6 \\
\hline $\mathrm{N}-\mathrm{NO}_{3}{ }^{-}\left(\mathrm{mg} \cdot \mathrm{L}^{-1}\right)$ & 0,1 \\
\hline $\mathrm{P}-\mathrm{PO}_{4}{ }^{3-}\left(\mathrm{mg} \cdot \mathrm{L}^{-1}\right)$ & 12 \\
\hline
\end{tabular}

TS: total solids, TVS: total volatile soilids, TSS: total suspended Solids, VSS: volatile suspended solids, TFS: total fixed solids. TP: total phosphorus. 
Table 2 - Co-substrates characteristics.

\begin{tabular}{|c|c|c|c|c|c|}
\hline & Milk serum & $\begin{array}{l}\text { WWTP } \\
\text { grease }\end{array}$ & $\begin{array}{l}\text { Collective } \\
\text { restaurant }\end{array}$ & $\begin{array}{l}\text { Urban } \\
\text { organic } \\
\text { waste }\end{array}$ & $\begin{array}{l}\text { White } \\
\text { sugar }\end{array}$ \\
\hline $\begin{array}{l}\text { TCOD } \\
\left({\left.\mathrm{g} \cdot \mathrm{kg}^{-1}\right)}\right.\end{array}$ & 64 & 123 & 315 & 336 & 1170 \\
\hline $\begin{array}{l}\text { TP } \\
\left(\mathrm{g} . \mathrm{kg}^{-1}\right)\end{array}$ & 0,6 & 0,2 & 0,4 & 1,4 & NP \\
\hline $\begin{array}{l}\text { TKN } \\
\left(\text { g.kg }^{-1}\right)\end{array}$ & 1,4 & 1,0 & 3,1 & 8,5 & NP \\
\hline $\begin{array}{l}\mathrm{N}-\mathrm{NH}_{4}^{+} \\
\left(\mathrm{g} \cdot \mathrm{kg}^{-1}\right)\end{array}$ & 0,0 & 0,2 & 0,2 & 0,4 & NP \\
\hline $\begin{array}{l}\text { Proteins } \\
\text { content* }\end{array}$ & $19,2 \%$ & $5,8 \%$ & $8,2 \%$ & $21,5 \%$ & NP \\
\hline $\begin{array}{l}\text { Lipids } \\
\text { content* }\end{array}$ & 2, 9\% & $48,8 \%$ & $31,6 \%$ & $47,4 \%$ & NP \\
\hline $\begin{array}{l}\text { carbohydrates } \\
\text { content* }\end{array}$ & $77,8 \%$ & $45,4 \%$ & $60,2 \%$ & $31,1 \%$ & NP \\
\hline
\end{tabular}

NP: not performed. *expressed in COD/TCOD. 
Table 3 - Experiment summary

\begin{tabular}{|c|c|c|c|c|c|}
\hline \multirow[b]{2}{*}{ Reactor } & \multirow[b]{2}{*}{ Total P } & \multirow[b]{2}{*}{ Co-substrate } & \multirow[b]{2}{*}{$\begin{array}{l}\text { Load } \\
\text { gCOD/gVS) }\end{array}$} & \multicolumn{2}{|l|}{$+48 \mathrm{~h}$} \\
\hline & & & & $\begin{array}{l}\text { Acidified } \\
\text { sample }\end{array}$ & $\begin{array}{l}\text { Reactor } \\
\text { intervention }\end{array}$ \\
\hline R1 & 782 & Control & 0 & to $\mathrm{pH} 4$; & $\begin{array}{l}\text { Continuing at } \mathrm{pH} 4 \\
\text { (HCl addition) }\end{array}$ \\
\hline R2 & 782 & Control & 0 & - & $\begin{array}{l}\text { white sugar addition, } 0.5 \\
\text { gTCOD/gTVS load }\end{array}$ \\
\hline R3 & 786 & $\begin{array}{l}\text { Collective } \\
\text { restaurant }\end{array}$ & 0.2 & to $\mathrm{pH} 4$ & $\begin{array}{l}\text { white sugar addition, } 0.5 \\
\text { gTCOD/gTVS load }\end{array}$ \\
\hline R4 & 796 & $\begin{array}{l}\text { Urban } \\
\text { organic waste }\end{array}$ & 0.2 & to $\mathrm{pH} 4$ & $\begin{array}{l}\text { white sugar addition, } 0.5 \\
\text { gTCOD/gTVS load }\end{array}$ \\
\hline R5 & 833 & Milk serum & 0.2 & to $\mathrm{pH} 4$ & $\begin{array}{l}\text { white sugar addition, } 0.5 \\
\text { gTCOD/gTVS load }\end{array}$ \\
\hline R6 & 765 & $\begin{array}{l}\text { WWTP } \\
\text { grease }\end{array}$ & 0.2 & to $\mathrm{pH} 4$ & $\begin{array}{l}\text { white sugar addition, } 0.5 \\
\text { gTCOD/gTVS load }\end{array}$ \\
\hline
\end{tabular}


Table 4 - Medium values and standard deviations of relevant molar ratios at the final situations.

\begin{tabular}{|l|l|l|l|l|}
\hline & $\mathrm{Mg}: \mathrm{P}$ & $\mathrm{N}: \mathrm{P}$ & $\mathrm{Mg}: \mathrm{Ca}$ & $\mathrm{Ca}: \mathrm{P}$ \\
\hline $\begin{array}{l}\text { Chemical } \\
\text { acidification } \\
\text { (after 48h) }\end{array}$ & $0.34 \pm 0.02$ & $2.52 \pm 0.32$ & $0.41 \pm 0.01$ & $0.83 \pm 0.06$ \\
\hline $\begin{array}{l}\text { Biological } \\
\text { acidification } \\
\text { (after 72h) }\end{array}$ & $0.37 \pm 0.03$ & $2.69 \pm 0.41$ & $0.41 \pm 0.02$ & $0.92 \pm 0.09$ \\
\hline $\begin{array}{l}\text { Biological } \\
\text { acidification } \\
\text { (after 96h) }\end{array}$ & $0.39 \pm 0.03$ & $3.04 \pm 0.49$ & $0.43 \pm 0.07$ & $0.92 \pm 0.09$ \\
\hline
\end{tabular}


Figure captions

Figure 1: Sequencing acidification strategy.

Figure 2: Soluble $\mathrm{P}$ and total soluble iron in chemical acidification test.

Figure 3: $\mathrm{pH}$ evolution.

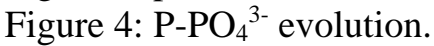

Figure 5: estimated distribution of phosphorus with sequencing acidification.

Figure 6: Evolution of calcium (A), magnesium (B), potassium (C) and ammonium (D) ion concentrations on sequencing acidification.

Figure 7: Evolution of soluble iron concentration on sequencing acidification. 


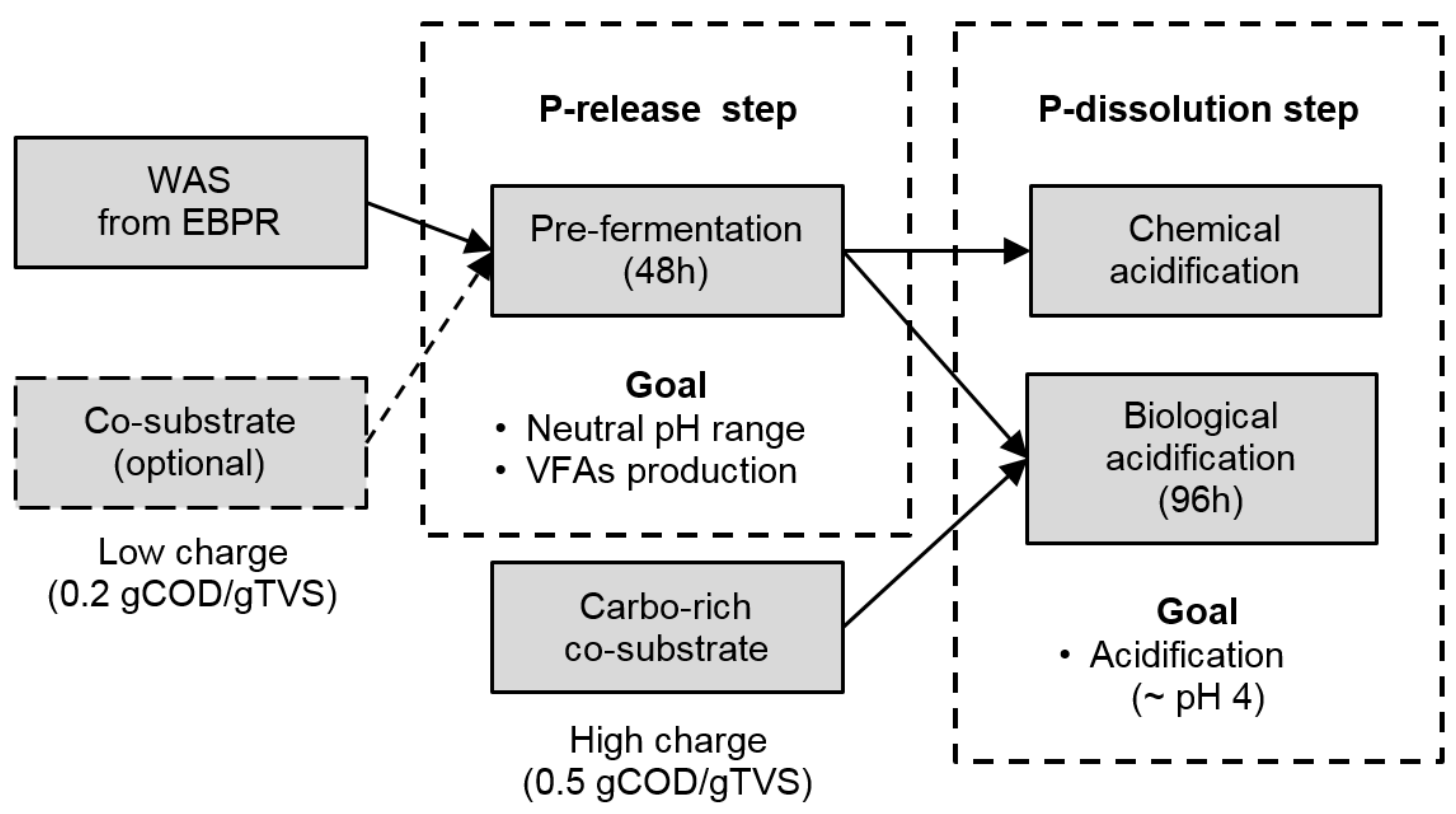




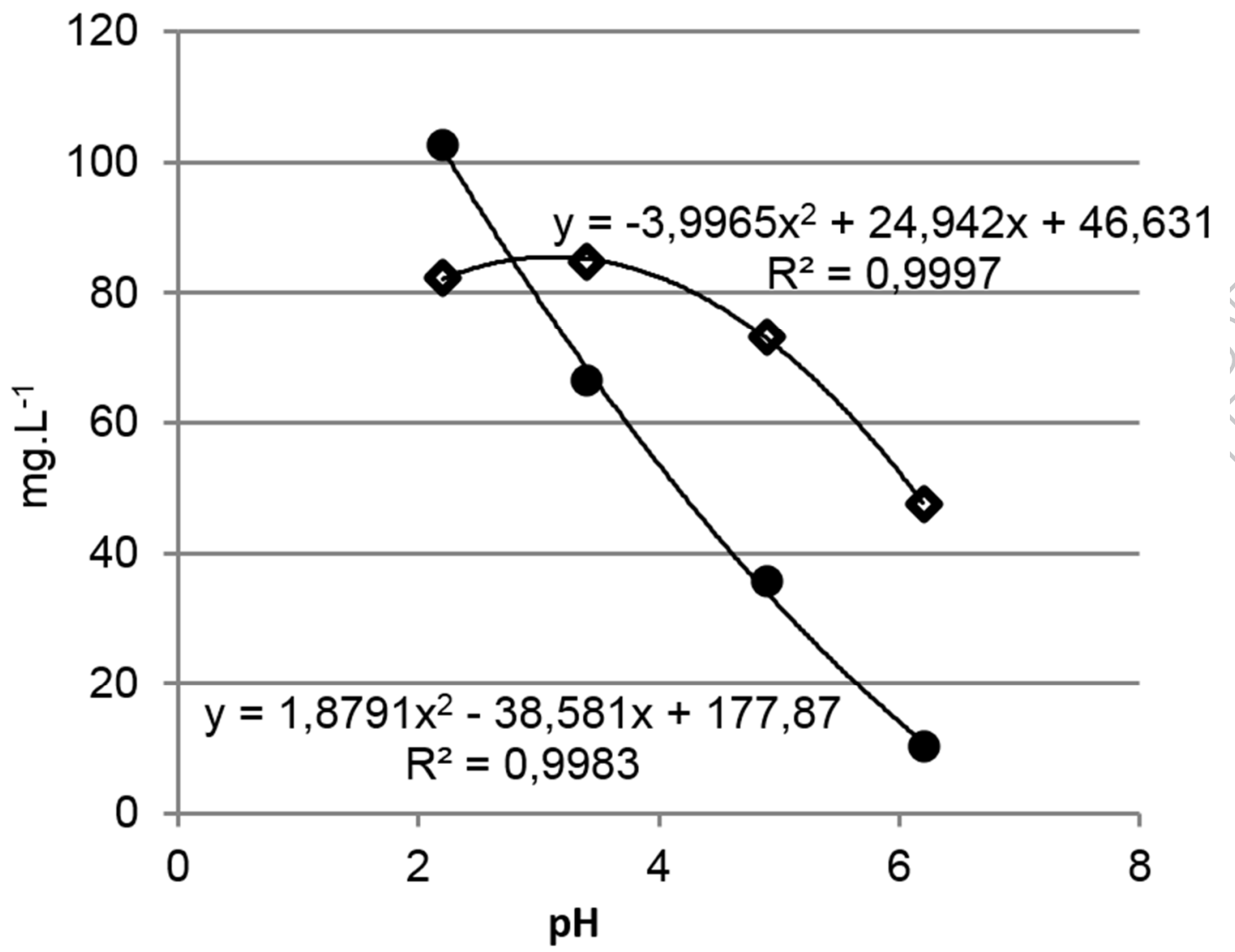

- Ortophosphates $\quad$ Total dissolved iron 


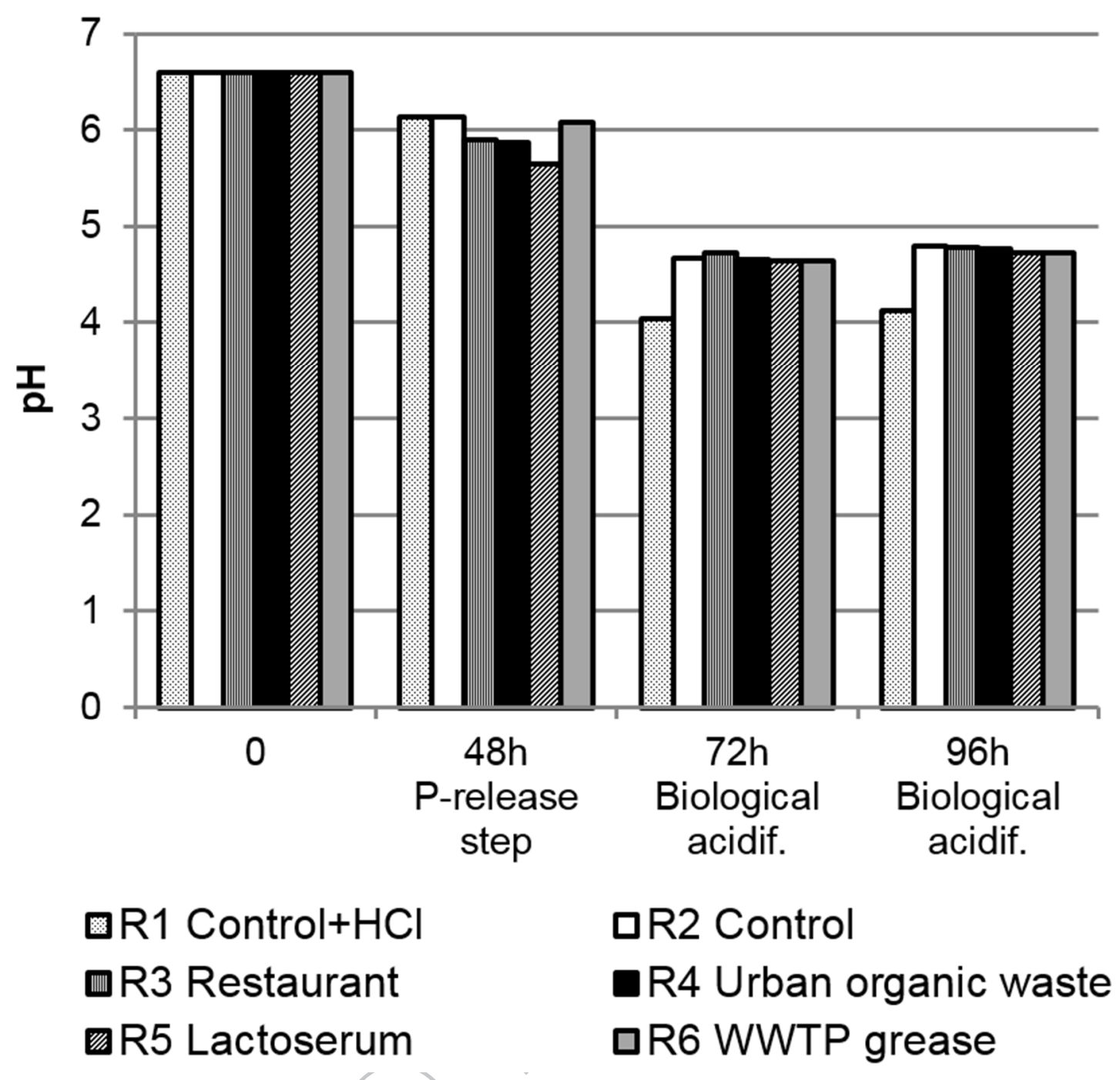




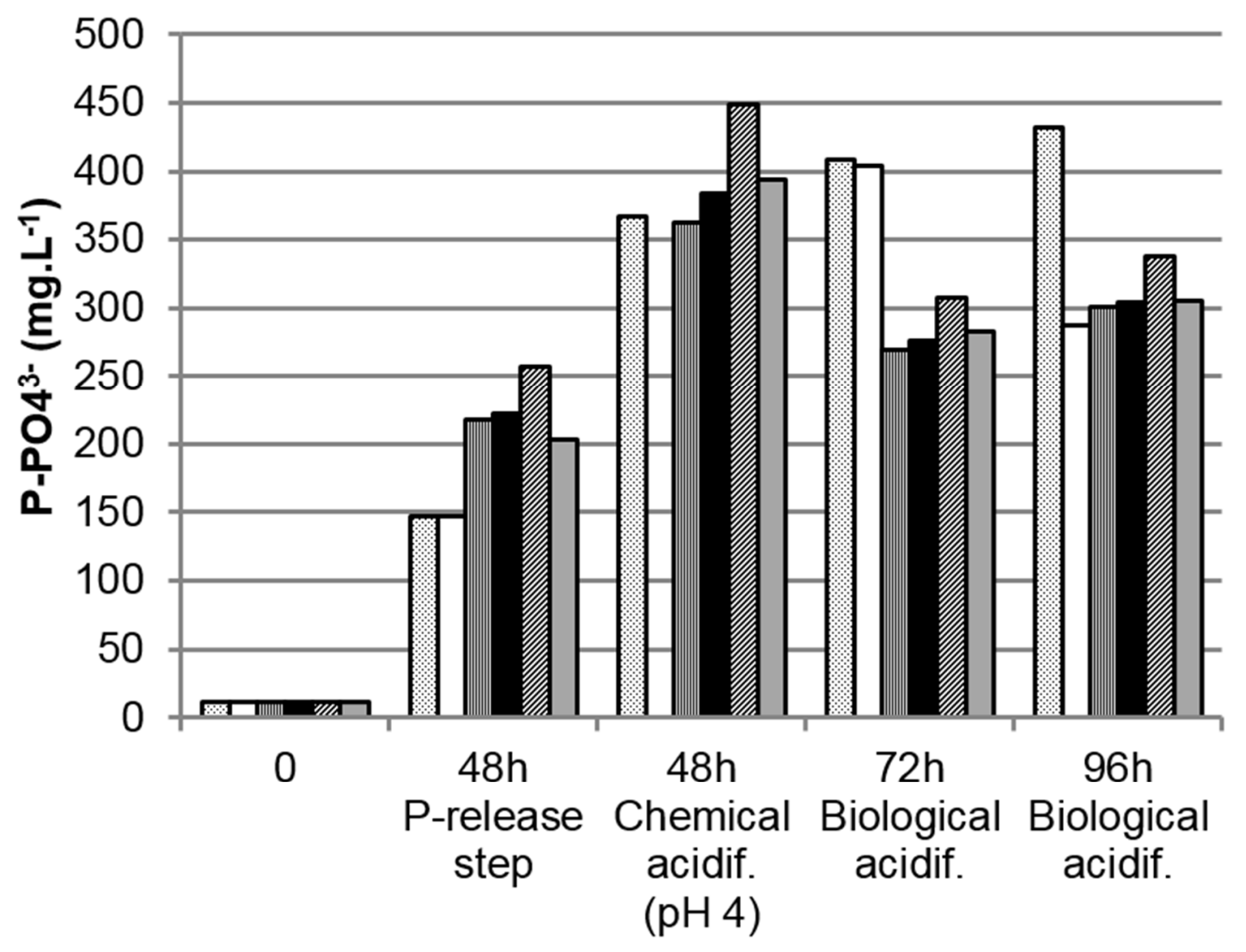

- $\mathrm{R} 1 \mathrm{Control}+\mathrm{HCl}$

口R2 Control

$\square$ R3 Restaurant

-R4 Urban organic waste

R5 Lactoserum

口R6 WWTP grease 


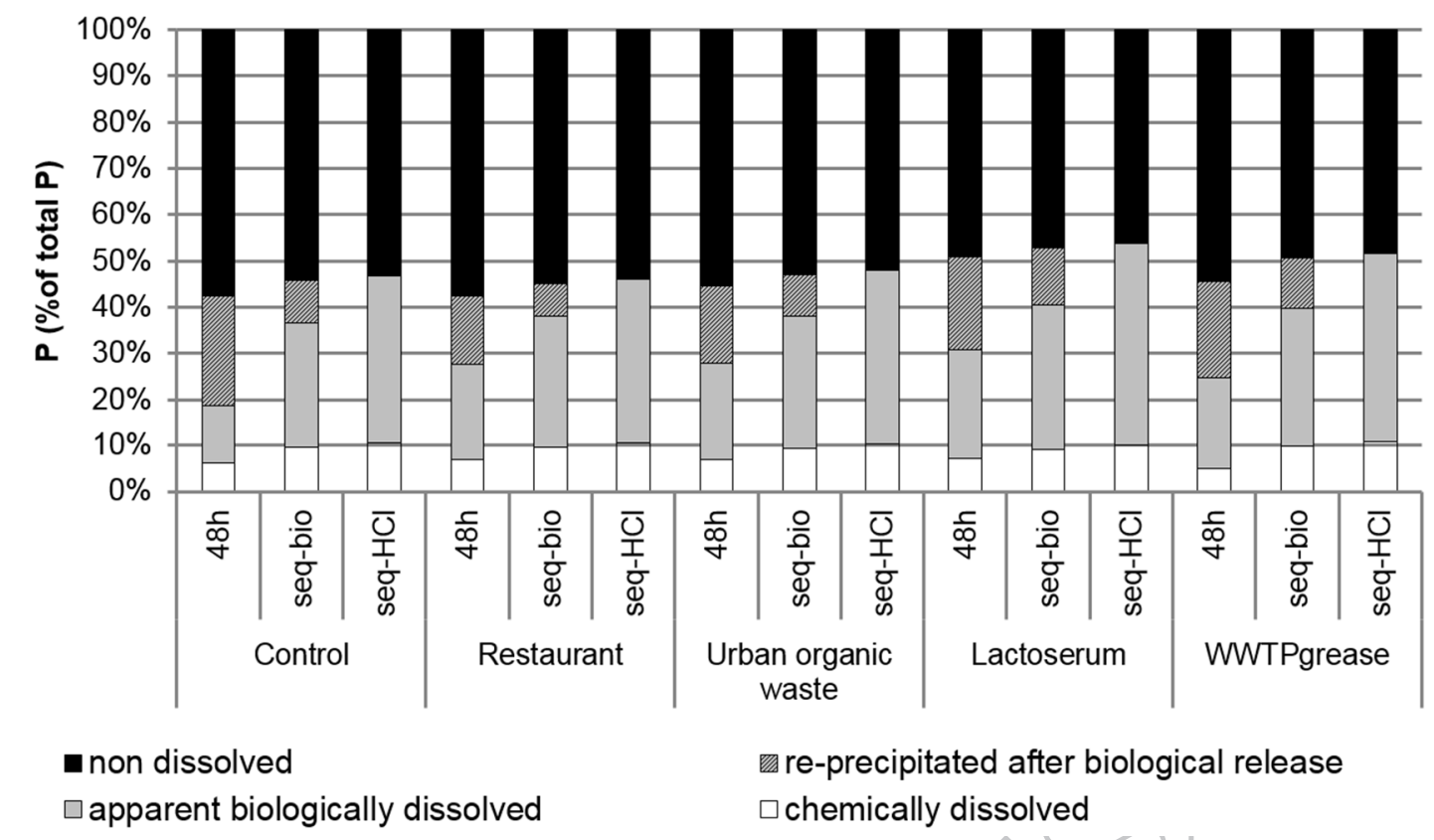


A

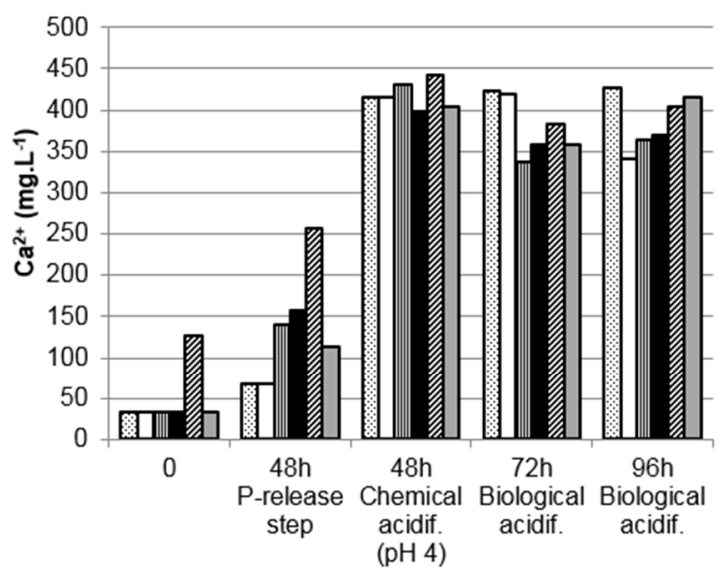

$\mathrm{C}$

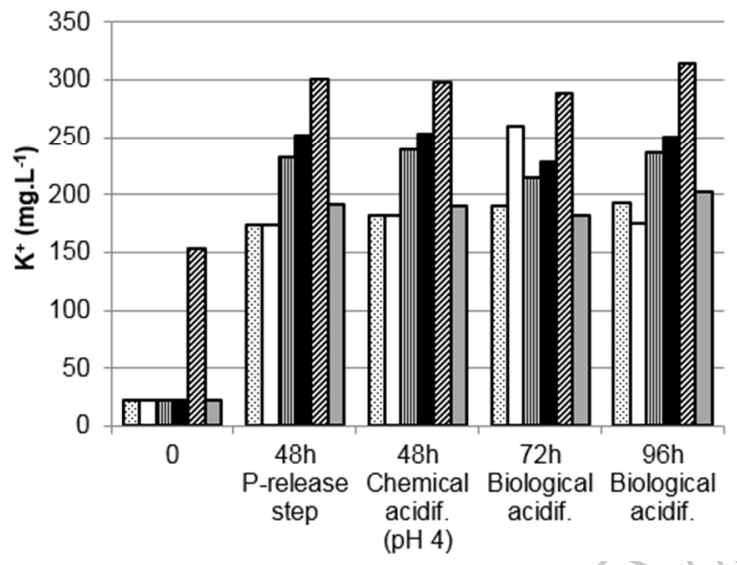

B

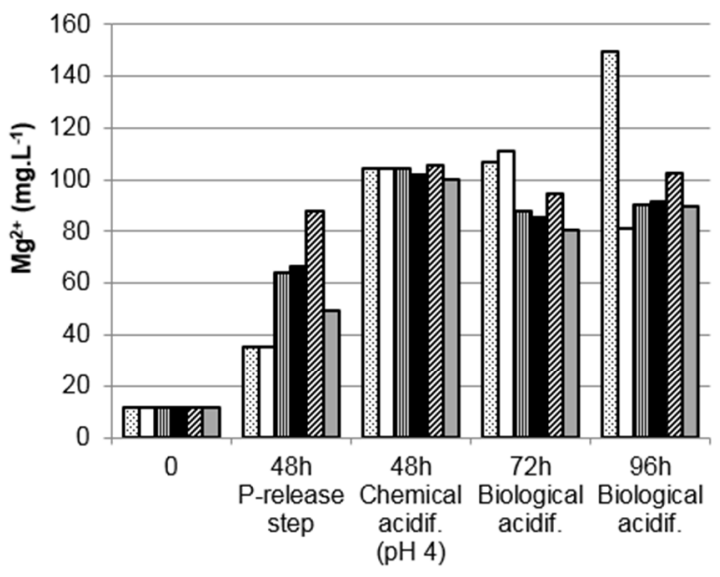

D

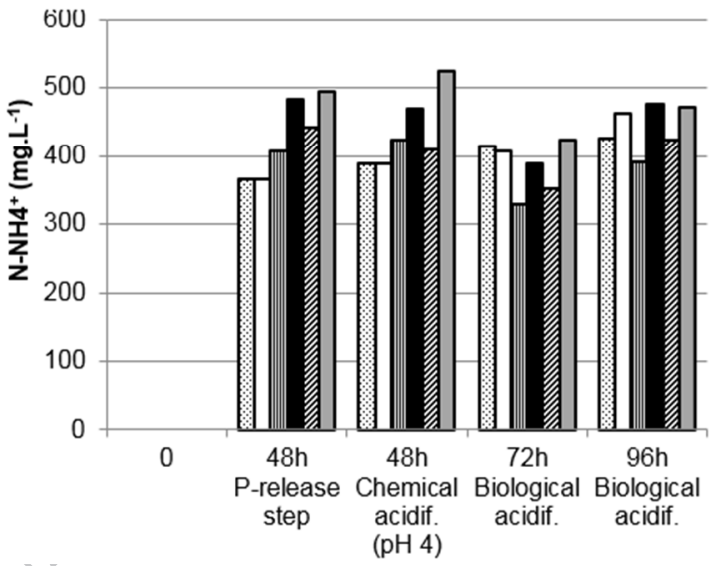




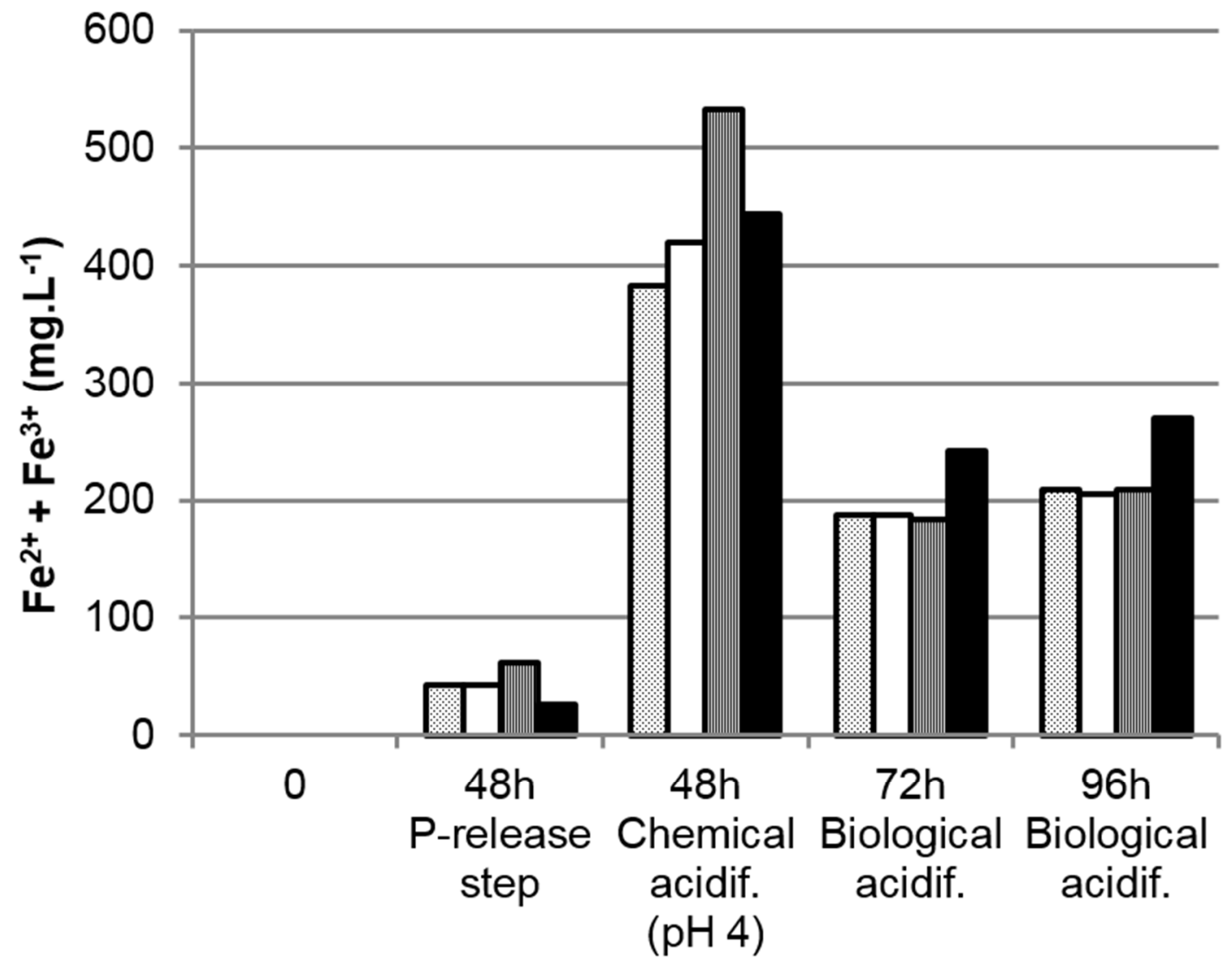

圆R3 Restaurant

口R4 Urban organic waste

四R5 Lactoserum

- R6 WWTP grease 


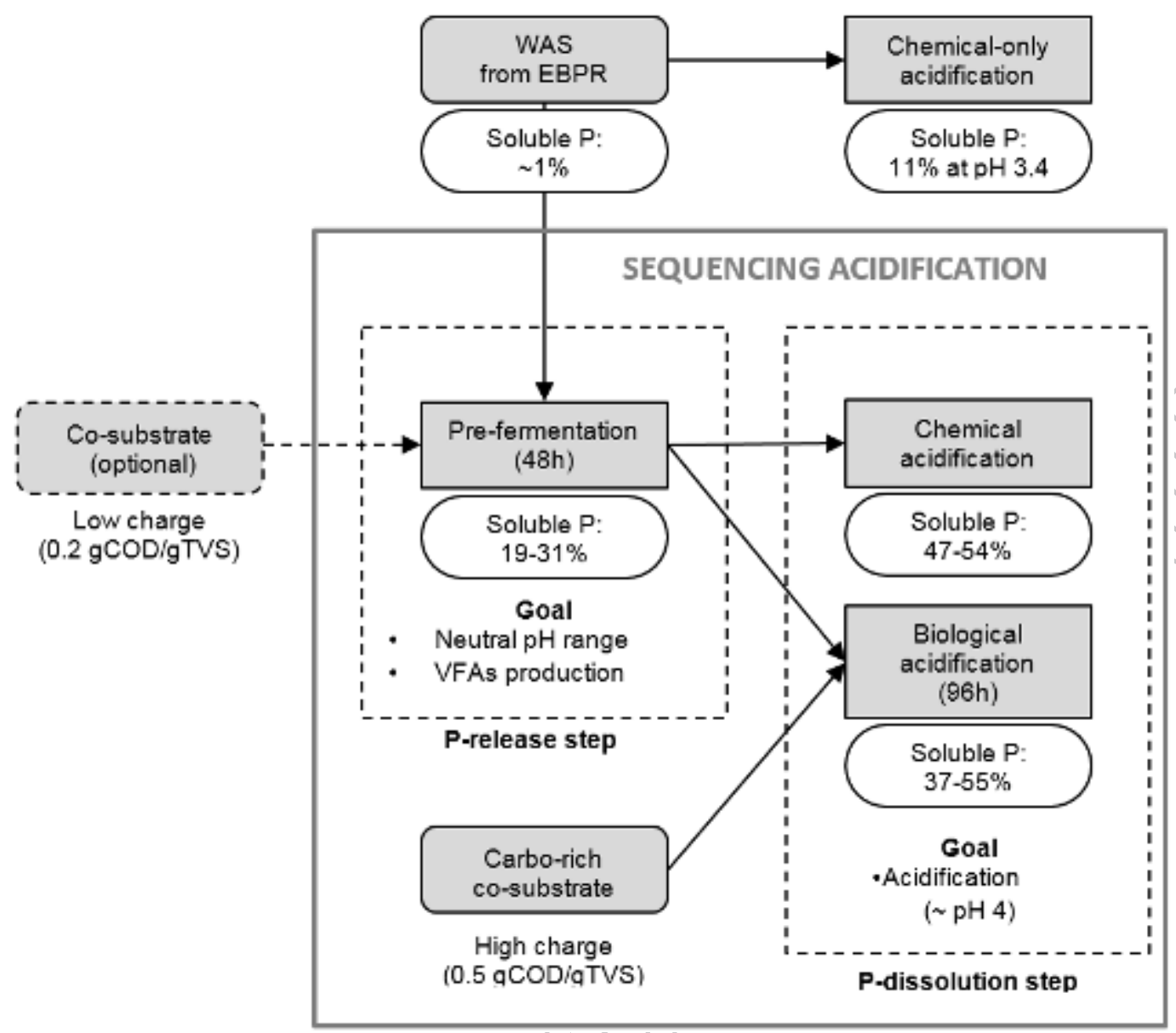

